УДК 338.26

\title{
БІЗНЕС-ПЛАНУВАННЯ ЯК ІНСТРУМЕНТ ЗДІЙСНЕННЯ ЗОВНІШНЬОЕКОНОМІЧНОЇ ДІЯЛЬНОСТІ НА ПІДПРИЕМСТВІ
}

\section{BUSINESS PLANNING AS A TOOL FOR IMPLEMENTING FOREIGN ECONOMIC ACTIVITIES AT THE ENTERPRISE}

\author{
Євтушенко Вікторія Анатоліївна \\ доктор економічних наук, профресор, \\ Харківський національний університет імені В.Н. Каразіна \\ ORCID: https://orcid.org/0000-0002-7764-2277 \\ шуба Тетяна Петрівна \\ кандидат економічних наук, доцент, \\ Харківський національний університет імені В.Н. Каразіна \\ ORCID: https://orcid.org/0000-0002-7163-2721 \\ Подлипян Інна Валеріївна \\ магістр, \\ Харківський національний університет імені В.Н. Каразіна \\ ORCID: https://orcid.org/0000-0003-0039-4137 \\ Yevtushenko Viktoriya, Shuba Tetyana, Podlipyan Inna \\ V.N. Karazin Kharkiv National University
}

\begin{abstract}
Мета статті полягає у дослідженні і вдосконаленні бізнес-планування в умовах розвитку зовнішньоекономічної діяльності підприємства. Даний інструмент господарської діяльності набуває особливого значення на етапі економічного розвитку, оскільки об'єктивно зростає потреба в більш детальному та комплексному застосуванні сучасних елементів планування для забезпечення життєздатності та запланованої конкурентоспроможності підприємства. Сучасна економічна ситуація, пов'язана з активним розвитком ринкових відносин та євроінтеграційним курсом країни, визначає новий підхід до внутрішнього та зовнішньоекономічного планування діяльності, які сьогодні набувають особливої актуальності. Проведено аналіз стосовно методології складання та ефективного впровадження бізнес-плану, на базі детального вивчення надано рекомендації щодо застосування при зовнішньоекономічній діяльності підприємства.
\end{abstract}

Ключові слова: бізнес-планування, зовнішньоекономічна діяльність, дослідження, підприємство, економічна ефрективність, ринок, стратегія.

Цель статьи состоит в исследовании и совершенствовании бизнес-планирования в условиях развития внешнеэкономической деятельности предприятия. Данный инструмент хозяйственной деятельности приобретает особое значение на этапе экономического развития, поскольку объективно растет потребность в более детальном и комплексном применении современных элементов планирования для обеспечения жизнеспособности и планируемой конкурентоспособности предприятия. Современная экономическая ситуация, связанная с активным развитием рыночных отношений и евроинтеграционным курсом страны, определяет новый подход к внутреннему и внешнеэкономическому планированию деятельности, которые сегодня приобретают особую актуальность. Проведен анализ методологии составления и эффрективного внедрения бизнес-плана, предоставлены рекомендации по применению при внешнеэкономической деятельности предприятия.

Ключевые слова: бизнес-планирование, внешнеэкономическая деятельность, исследование, предприятие, экономическая эффрективность, рынок, стратегия.

The purpose of the article is to analysis and improve business planning in the context of the development of foreign economic activity of the enterprise. This tool of economic activity acquires particular importance at the stage of economic development, since the need for a more detailed and comprehensive application of modern planning 
elements to ensure the viability and planned competitiveness of the enterprise is objectively increasing. The main provisions of the scientific novelty are the determination of the features of the development and presentation of business plans, as well as the justification of the feasibility of their development independently and using international standards. It is on the basis of planning the further behavior of its business in the international market that the company gets a real opportunity to minimize the internal and part of the external risks of the company, to maintain the flexibility of company management. A business plan for foreign economic activity is a document that analyzes the main problems that an enterprise may face in carrying out its activities in the international arena, and determines the main ways to solve these problems. It is with the help of a business plan for foreign economic activity that the top management of an enterprise can assess what market shocks its business can withstand, and adequately cope with many inevitable problems. The modern economic situation associated with the active development of market relations and the country's course towards European integration determines a new approach to internal and external economic planning of activities, which is becoming especially relevant today. Business plan for foreign economic activity is a systematic assessment of the prospects for the development of an organization based on the analysis of factors of the internal and external environment. The planning process itself encourages the entrepreneur to objectively look at his business from all angles. Foreign practice of managing enterprises that have achieved significant success in business uses business planning among the many applied management methods. The analysis of the methodology for drawing up and effective implementation of the business plan is carried out, recommendations are given for use in the foreign economic activity of the enterprise.

Keywords: business planning, foreign economic activity, research, enterprise, economic efficiency, market, strategy.

Постановка проблеми. Бізнес-план включає практично всі фрункціональні напрямки діяльності підприємства, від детального опису технології бізнес-проекту до поглиблених фрінансових розрахунків економічної ефрективності. Тому контроль за розробкою та впровадженням суттєво сприяє як підвищенню ефективності, так і зниженню ризиків створення нових напрямків підприємницької діяльності. Розвиток ринкових відносин в Україні та проведення рефрорм супроводжуються лібералізацією зовнішньоекономічної діяльності. Правильно складений план зовнішньоекономічної діяльності сприяє отриманню додаткових прибутків за рахунок більш повного використання переваг міжнародної праці та міжнародної інтеграції, а також визначенню перспектив і можливих варіантів розвитку зовнішньоекономічної діяльності підприємств.

Аналіз останніх досліджень і публікацій. Теоретичні та практичні питання щодо бізнес-планування на підприємстві розглянуті в працях вітчизняних науковців, спеціалізованих журналах та електронних видань: "Економіка та Держава", "Економіка та управління підприємствами", "Есрективна економіка", Державна служба статистики України, United Nations Industrial Development Organization тощо. Окремі теоретичні і прикладні аспекти фрункціонування на зовнішньоекономічному ринку підприємства із застосуванням ефрективного бізнес-плану досліджені в працях науковців: Алексеєва М. М., Бражник О. С., Вероніна Н. І., Габа М. І., Дроздова Г. М., Лосєва Х. Г., Марич М. Г., Покропивний С. Ф., Хопчан М. І., Ясинський В. В. та ін.

Виділення невирішених раніше частин загальної проблеми. В той же час окремі теоретико-методичні аспекти бізнес-планування потребують додаткового дослідження із урахуванням оновленого економічного простору та успішного досвіду підприємств на зовнішньому ринку.

Формулювання цілей статті (постановка завдання). Дослідження теоретичних та практичних положень бізнес-планування як складного процесу прийняття управлінських рішень на підприємстві в умовах євроінтеграційного курсу України.

Виклад основного матеріалу дослідження. Провідну роль у розвитку та фрункціонуванні підприємств відіграє зовнішньоекономічна діяльність. Під зовнішньоекономічною діяльністю розуміють діяльність суб'єктів господарювання України та іноземних суб'єктів господарювання, яка побудована на відносинах між ними і здійснюється як на території України, так і за ії межами [1]. Розробка бізнес-плану є важливою і корисною процедурою з точки зору управління підприємством, оскільки бізнесплан чітко і детально описує перспективи діяльності компанії, показує, як її керівники планують досягти поставленої мети (рис. 1).

Опрацювання бізнес-плану як складного багатофрункціонального документа має кілька цілей, а саме:

- залучення зовнішнього капіталу (містить інфрормацію не тільки про виробництво, ринок, організації, а й фрінансові аспекти майбутнього бізнесу);

- комунікаційний інструмент (стандартизує процедуру знайомства з бізнесом, економить час і організовує контакти);

- моделювання системи управління бізнесом (моделювання системи управління май- 
Бізнес-план зовнішньоекономічної діяльності визначається як спеціальний інструмент управління, який широко використовується практично в усіх галузях сучасної ринкової економіки, незалежно від розміру, форми приналежності та сфери діяльності компанії.

Зовнішня (ознайомлення різних
$\begin{aligned} & \text { представників ділового світу } \\ & \text { аспектамтером та основними реалізації конкретної } \\ & \text { підприємницької ідеї) }\end{aligned}$

Рис. 1. Сутність та призначення бізнес-плану

Джерело: розроблено автором за [2]

бутнім бізнесом, ризиками, відносинами 3 партнерами, стейкхолдерами).

Процес складання бізнес-плану індивідуальний для кожного конкретного випадку. Незалежно від ссрери діяльності та особливостей компанії, яка готує бізнес-план, можна виділити кілька стандартних етапів, які необхідно послідовно пройти під час його розробки:

1. Визначення мети написання бізнесплану (визначається переліком проблем, для вирішення яких розробляється бізнес-план).

2. Чітке визначення переліку тих, кому буде надано бізнес-план (для внутрішнього використання керівниками підприємства або призначений для інвесторів, комерційних банків, хедж-срондів тощо).

3. Збір інсрормації, необхідної для написання бізнес-плану.

4. Вибір структури бізнес-плану та його розробка [3].

При складанні бізнес-плану підприємству необхідно надати більше інфрормації відносно маркетингової, виробничої, фрінансової, загальноекономічної та галузевої сторін. Джерелами отримання даних можуть бути власний досвід практичної діяльності у виробничій ссрері, контакти 3 майбутніми постачальниками або споживачами, відомості про конкурентів, статистична інформація про стан і тенденції розвитку ринку, поточні аналітичні огляди економічної ситуації, публікації 3 питань підприємництва [3].

Зміст і структура бізнес-плану не мають суворо регламентованої форми для зовнішнього ринку, але, як правило, він містить розділи, що розкривають концепцію та мету бізнесу, характеризують специсріку продукту компанії та задовольняють потреби ринку. Він також оцінює місткість ринку та встановлює стратегію поведінки компанії на окремих сегментах ринку, визначає організаційну та виробничу структуру, фрормує срінансовий проект справи, включаючи стратегію фрінансування та інвестиційних пропозицій та зростання компанії. описано перспективи зовнішньоекономічної діяльності [4]. В цілому, бізнес-план включає в себе: резюме (короткий опис проекту), опис промисловості, продукту або послуги, маркетинг та продаж продукції, виробничий, фрінансовий та організаційний плани, ризики, гарантії.

Доцільність ефективного бізнес-планування в його використанні полягає у здатності підприємства:

- розширювати або модернізувати виробництво;

- освоєння новітніх ринків (продуктів, послуг);

- відкривати нові напрямки діяльності;

- отримати доступ до кредитної лінії; брати участь у спільному підприємстві; 
- донести до інвестора бізнес-ідеї та підприємницькі рішення.

Помилки найчастіше трапляються на етапі розробці та представленні бізнес-плану (табл. 1). Деякі з них можуть здатися недостатньо важливими і серйозними, але якщо бізнес-план складений правильно, то він дозволяє вирішити такі проблеми, як: постановка ключових цілей перед керівниками; полегшує аналіз і подальшу реалізацію бізнес-ідей; залучення необхідних інвесторів [5].

Слід зазначити, що незважаючи на зазначені недоліки, експертні оцінки підтверджують, що самостійна розробка бізнес-плану та бажання компанії створити власну систему бізнес-планування дає більш сприятливі та позитивні результати, ніж звернення до консалтингових та аудиторських компаній, які надають подібні послуги. По-перше, це заощадить кошти компанії, а по-друге, дозволить скласти більш об'єктивний бізнес-план відповідно до ваших потреб, можливостей та очікувань. Хоча цілком зрозуміло, що великі та середні підприємства можуть дозволити собі замовити експертний висновок для розробки бізнес-плану або підтримувати власний відділ у своїй організаційній структурі у відповідних бізнес-планувальників.

Можна зробити висновок, що бізнес-план зовнішньоекономічної діяльності - це вичерпний опис бізнесу та середовища, в якому він діє, а також системи управління, в якій він повинен досягати своїх цілей. Таким чином, бізнес-план зовнішньоекономічної діяльності в цілому служить для:

- визначення цілей зовнішньоекономічного проекту;

- сприяння розробці зовнішньоекономічної стратегії та оперативної тактики для досягнення цілей підприємства;

- створення системи вимірювання продуктивності праці;

- забезпечення інструментів управління зовнішньоекономічною діяльністю підприємства;

- надання оцінки сильних і слабких сторін компанії на міжнародному ринку, а також визначення альтернативних стратегій подолання [6].

Помилки, що трапляються при розробці бізнес-плану підприємства

\begin{tabular}{|c|c|}
\hline Назва помилки & Сутність та характеристика \\
\hline $\begin{array}{c}\text { Стилістика } \\
\text { викладу }\end{array}$ & $\begin{array}{l}\text { Орорографрія, пунктуація, стиль мовлення важливі складові бізнес-плану, } \\
\text { відсутність яких може призвести до того, що іноземний інвестор поставить } \\
\text { під сумнів можливості компанії з точки зору відповідної організації бізнесу }\end{array}$ \\
\hline $\begin{array}{l}\text { Недбалість } \\
\text { у дизайні }\end{array}$ & $\begin{array}{l}\text { Цей недолік означає бізнес-план, який не має змісту, розбитого на } \\
\text { сторінки, заголовків таблиць, даних діаграми, великої кількості технічної } \\
\text { термінології, яку можна пояснити простою мовою, тощо }\end{array}$ \\
\hline Брак інорормації & $\begin{array}{l}\text { Бізнес-план повинен містити інформацію з таких питань, як клієнти } \\
\text { компанії, продукт, маркетинг, фрінанси, управлінська команда, конкуренти. } \\
\text { Відповідно, необхідно розробити фрінансові прогнози, показники руху } \\
\text { грошових коштів, річні баланси та фрінансовий план підприємства }\end{array}$ \\
\hline $\begin{array}{c}\text { Невизначеність } \\
\text { результатів }\end{array}$ & $\begin{array}{l}\text { Відсутність чітких результатів унеможливлює фрінансування проекту. У } \\
\text { цьому випадку інвестор не до кінця розуміє очікування компанії, мету } \\
\text { свого проекту та кінцевий результат через свій прибуток. У такій ситуації } \\
\text { резюме має зацікавити інвестора настільки, щоб він захотів ознайомитися } \\
\text { з додатковою та детальною інфрормацією, що міститься в бізнес-плані }\end{array}$ \\
\hline $\begin{array}{l}\text { Надлишкова } \\
\text { інфорорація }\end{array}$ & $\begin{array}{l}\text { Бізнес-план не повинен містити зайвих деталей, зокрема пов'язаних з } \\
\text { описом існуючих послуг і товарів, якими займається компанія. Також він } \\
\text { повинен бути не занадто великим, але змістовним, лаконічним і чітким у } \\
\text { викладі основної підприємницької ідеї. Бізнес-план не повинен бути надто } \\
\text { насиченим технічними термінами, навряд чи він зацікавить інвестора, } \\
\text { який, можливо, не знайомий з цією темою. Якщо для запропонованого } \\
\text { проекту важливі технічні деталі, то до бізнес-плану можна скласти } \\
\text { спеціальний технічний додаток, де можуть бути представлені технічні } \\
\text { схеми та відповідні пояснення до них }\end{array}$ \\
\hline $\begin{array}{l}\text { Відсутність } \\
\text { конкуренції }\end{array}$ & $\begin{array}{l}\text { Найпоширенішою помилкою, яку можна простежити при розробці бізнес- } \\
\text { планів, є ситуація, коли компанія вважає, що у неї немає конкурентів. } \\
\text { Ця думка помилкова, оскільки у кожного бізнесу є принаймні непрямі } \\
\text { конкуренти. Тому при розробці бізнес-плану необхідно детально } \\
\text { проаналізувати ринкову ситуацію, в якій компанія зайняла свою нішу }\end{array}$ \\
\hline
\end{tabular}


Висновки. Ефективний бізнес-план зовнішньоекономічної діяльності сприяє зростанню фрінансових результатів кожного підприємства. Для правильної структури, подальшого фрункціонування та розвитку будь-якого підприємства необхідне детальне планування. Особливо при створенні нового напрямку, виду економічної діяльності чи стратегічного підрозділу підприємства важливо створити бізнес-план як детальний попередній аналіз і прогноз доцільності підприємницького проекту.

Бізнес-план господарської діяльності набуває особливого значення на етапі економічного розвитку, оскільки цілеспрямовано зростає потреба в більш детальному і ком- плексному застосуванні сучасних елементів планування для забезпечення есрективності та планової конкурентоспроможності підприємства.

Розробка та реалізація ефективних управлінських рішень $€$ важливою умовою забезпечення конкурентоспроможності продукції організації на ринку, а також створення оптимальної організаційної структури, реалізації стабільної кадрової політики та впорядкування інших аспектів діяльності організації. Тому контроль за розробкою та впровадженням (у майбутньому) значною мірою сприяє як підвищенню ефрективності, так і зниженню ризиків у створенні нових напрямків підприємницької діяльності.

\section{СПИСОК ВИКОРИСТАНИХ ДЖЕРЕЛ:}

1. Василюк В. В. Бізнес-планування як інструмент управління витратами харчового виробництва. Моделювання регіональної економіки. 2014. № 1. С. 218-224.

2. Покропивний С. Ф., Соболь С. Ф., Швиденко Г. О., Дерев'янко О. Г. Бізнес-план: технологія розробки та обґрунтування : навч. посіб. Вид. 2-ге, доп. Київ : КНЕУ, 2010. 379 с.

3. Лосєва Х. Г. Реінжиніринг бізнес-планування як процес вдосконалення управління конкурентоспроможністю підприємства. Економіка та держава. 2012. № 2. С. 101-102.

4. Алексеєва М. М. Планування діяльності фірми : навч. посіб. Київ : Фінанси і статистика, 2011. 248 с.

5. Коваленко О. М., Шаповал С. С. Особливості складання бізнес-плану зовнішньоекономічної діяльності. Наука: теорія і практика : зб. матеріалів учасн. IV Міжнар. наук.-практ. конфр. Прага : Дом «Наука и образование», 2008. С. 29-31.

6. Арапова О. М. Використання бізнес-плану для підвищення ефективності зовнішньоекономічної діяльності підприємства. Економіка: реалії часу. 2013. № 1. С. 71-75.

\section{REFERENCES:}

1. Vasilyuk, V. V. (2014) Biznes-planuvannya yak instrument upravlinnya vitratami harchovogo virobnictva [Business planning as a tool for food production cost management]. Modelyuvannya regionalnoyi ekonomiki - Modeling of the regional economy, no. 1, pp. 218-224. (in Ukrainian)

2. Pokropivnij, S. F., Sobol, S. F., Shvidenko, G. O., Derev'yanko, O. G. (2010) Biznes-plan: tehnologiya rozrobki ta obgruntuvannya [Business plan: technology development and justification]: textbook. way. Kyiv: KNEU, 2nd ed., 379 p. (in Ukrainian)

3. Losyeva, H. G. (2012) Reinzhiniring biznes-planuvannya yak proces vdoskonalennya upravlinnya konkurentospromozhnistyu pidpriyemstva [Business planning reengineering as a process of improving the competitiveness of the enterprise]. Ekonomika ta derzhava - Economy and state, no. 2, pp. 101-102. (in Ukrainian)

4. Alekseyeva, M. M. (2011) Planuvannya diyalnosti firmi [Company activity planning]: textbook. way. Kyiv: Finansi i statistika, 248 p. (in Ukrainian)

5. Kovalenko, O. M., Shapoval, S. S. (2008) Osoblivosti skladannya biznes-planu zovnishnoekonomichnoyi diyalnosti [Features of drawing up a business plan for foreign economic activity]. Proceedings from STPISP' 8: Science: theory and practice: coll. materials of participants IV International. scientific-practical conf. - Nauka: teoriya i praktika: zb. materialiv uchasn. IV Mizhnar. nauk.-prakt. konf. Praga: Dom «Nauka i obrazovanie», pp. 29-31. (in Ukrainian)

6. Arapova, O. M. (2013) Vikoristannya biznes-planu dlya pidvishennya efektivnosti zovnishnoekonomichnoyi diyalnosti pidpriyemstva [Using a business plan to increase the efficiency of foreign economic activity of the enterprise]. Ekonomika: realiyi chasu - Economics: the realities of time, no. 1, pp. 71-75. (in Ukrainian) 